Case Reports in
Gastroenterology
Case Rep Gastroenterol 2020;14:467-471

DOI: 10.1159/000508441

Published online: October 8, 2020

(C) 2020 The Author(s)

Published by S. Karger AG, Basel

www.karger.com/crg

This article is licensed under the Creative Commons Attribution-NonCommercial 4.0 International License (CC BY-NC) (http://www.karger.com/Services/OpenAccessLicense). Usage and distribution for commercial purposes requires written permission.

\title{
Bleeding Gastric Heterotopic Polyp in the Duodenum of a Teenager with Severe Factor VII Deficiency
}

\author{
Eric E. Tibesar \\ Pediatric Gastroenterology, Peyton Manning Children's Hospital, Indianapolis, IN, USA
}

\section{Keywords}

Abdominal pain · Capsule endoscopy · Case report · Endoscopy · Gastrointestinal bleeding . Small intestine $\cdot$ Surgery $\cdot$ Treatment

\begin{abstract}
Heterotopic gastric tissue can be found throughout the intestinal tract, and when it is present in the small intestine, it can present with symptoms that include gastrointestinal bleeding, chronic abdominal pain, diarrhea, and chronic dyspepsia. This finding is incredibly rare in pediatrics, but if present, it can lead to significant morbidity and mortality. This can be especially true if a patient presents with a comorbidity of a bleeding disorder. We here present the case of a teenage male with a history of severe factor VII deficiency who was found to have iron deficiency anemia resulting in multiple blood transfusions from an occult lower gastrointestinal bleed. He was ultimately found to have a bleeding gastric heterotopic polyp in his duodenum that was successfully removed via surgery.

(C) 2020 The Author(s)

Published by S. Karger AG, Basel
\end{abstract}

\section{Introduction}

Heterotopic gastric mucosa in the small intestine is a very rare congenital finding that can present with a variety of different symptoms including gastrointestinal bleeding, chronic abdominal pain, bowel obstruction, intussusception, diarrhea, and chronic dyspepsia [1-9]. This type of abnormal tissue can be found in many different areas of the gastrointestinal tract 


\section{Case Reports in Gastroenterology}

Case Rep Gastroenterol 2020;14:467-471 DOI: $10.1159 / 000508441$

(c) 2020 The Author(s). Published by S. Karger AG, Basel www.karger.com/crg

Tibesar: Gastric Heterotopic Polyp in a Teenager with Bleeding Disorder

including the rectum, gallbladder, cystic duct, and most commonly in the esophagus. If left unchecked, this type of tissue can lead to gastric ulcers due to high amounts of acid secretion as well as fistulous tracts, strictures, and esophageal webs, and rarely can be a precursor to adenocarcinoma [10-12]. Data in pediatrics about the incidence and prevalence of this finding are rare, but there have been reports of patients as young as 1 year presenting with this type of tissue found at pathology [1]. Diagnosis can be exceedingly difficult and involves a combination of endoscopy, surgery, and pathological analysis. Certainly, patients with other comorbidities can present a unique diagnostic dilemma as well as complicate the regular, normal treatment protocol. Here we present the case of a teenage patient with a severe bleeding disorder who presented with significant iron deficiency anemia and lower gastrointestinal bleed.

\section{Case Report}

The patient was a 16-year-old male with a past medical history significant for severe factor VII deficiency who presented with a several months' history of iron deficiency anemia requiring multiple blood transfusions and positive Hemoccult stool tests. His history extends back to when he was around 10 years of age and was found to have severe iron deficiency anemia also with Hemoccult-positive stool, so that he was referred to pediatric gastroenterology for evaluation. An extensive workup was done at the time that included upper endoscopy, colonoscopy, Meckel's scintigraphy, a nuclear medicine bleeding scan, and capsule endoscopy. The nuclear medicine bleeding scan showed some increased uptake in the second portion of the duodenum, but his upper endoscopy was visually normal and the remainder of his workup all came back within normal limits. Throughout this time, he was treated with multiple, repeat blood transfusions and was managed by pediatric hematology.

At the time of presentation, he was receiving approximately 2-3 blood transfusions per week as well as iron transfusions, but his blood work continued to worsen. His hemoglobin level had dropped to $8.6 \mathrm{~g} / \mathrm{dL}$ with a hematocrit level of $27.7 \%$. His ferritin level had also reached a low of $12.7 \mathrm{ng} / \mathrm{mL}$ with a reticulocyte count elevated at $4.5 \%$. His Hemoccult stool tests continued to remain positive. He underwent an upper gastrointestinal barium contrast study with small bowel follow-through in anticipation of a repeat capsule endoscopy for further evaluation that was ultimately read as normal. During capsule endoscopy evaluation, it was discovered that he had a large polypoid growth in approximately the third portion of the duodenum, just proximal to the ligament of Treitz, that was actively bleeding (Fig. 1). At that point, it was decided that a repeat upper endoscopy would be performed with possible enteroscopy and polypectomy. The patient was admitted to the hospital the day prior to the procedure with pediatric hematology consulted for administration of NovoSeven RT to help with bleeding control due to his factor VII deficiency. During the upper endoscopy, a large polypoid lesion was noted near the ligament of Treitz that had a notable clot from a prior bleed but no other abnormal surrounding mucosa (Fig. 2). The tissue was extremely friable, and based on the size of the lesion as well as its position in the duodenum, combined with the patient's bleeding disorder, it was felt that it would be safer to remove the polyp via surgery with partial bowel resection rather than endoscopic polypectomy. The lesion was biopsied once with cold forceps and was then tattooed and the patient was given several doses of factor VII for hemostasis. The next day, surgery was consulted, and the child was taken back to the operating room for robotic resection. A small 2- to 3-cm section of jejunum near the ligament of Treitz was ultimately resected and a primary end-to-end anastomosis was created with no significant bleeding or any other complications. The bowel section was sent to pathology and the 


\section{Case Reports in Gastroenterology}

\begin{tabular}{l|l}
\hline Case Rep Gastroenterol 2020;14:467-471 \\
\hline DOI: 10.1159/000508441 & $\begin{array}{l}\text { ○ 2020 The Author(s). Published by S. Karger AG, Basel } \\
\text { www.karger.com/crg }\end{array}$ \\
\hline
\end{tabular}

Tibesar: Gastric Heterotopic Polyp in a Teenager with Bleeding Disorder

patient recovered without concerns. He was started on high-dose proton pump inhibitor therapy and discharged home on postoperative day 4 . The patient had a pediatric gastroenterology follow-up appointment approximately 2 months after surgery where he was found to be asymptomatic and was eventually weaned off his proton pump inhibitor with no further follow-up recommended. His intestinal pathology came back showing duodenal mucosa with gastric heterotopia that was negative for dysplasia or carcinoma. He continues to be followed by pediatric hematology but is no longer receiving frequent blood transfusions and no longer having any significant gastrointestinal symptoms.

\section{Discussion}

Heterotopic gastric mucosa is a very rare finding in the small intestine of pediatric patients and even a rarer cause of lower gastrointestinal bleeding. These types of lesions have been reported in the duodenum and small intestine of pediatric patients of all ages, but to our knowledge this is the first report of a patient who presented with severe iron deficiency anemia from a lower gastrointestinal bleed who also had a concomitant factor VII deficiency. Because of this comorbidity, the patient's diagnosis and treatment was far more complicated. He was at an increased risk of severe bleeding complications from his endoscopy and follow-up surgery, but fortunately he was managed carefully and suffered no significant harm.

Currently, data are quite limited in pediatric patients when it comes to the incidence and prevalence of heterotopic gastric mucosa in the small intestine. There have been reports that the incidence varies from 0.5 to $8.9 \%$ in the duodenum whereas the esophagus appears to be the most common site for heterotopic gastric mucosa [1]. These types of lesions have caused several different symptoms and complications in patients as it has been reported that severe intestinal obstruction, perforation, and chronic abdominal pain with vomiting and diarrhea are different presenting signs [1-5]. As in our case, the heterotopic gastric mucosa was located in a large polyp that caused a significant bleed, likely worsened by the patient's underlying bleeding disorder. Many times, polypoid heterotopic gastric mucosa can be found incidentally at endoscopic evaluation and may present with no symptoms at all of bleeding or abdominal pain. Diagnosis very commonly consists of endoscopic evaluation and, as in our case, additional imaging tests such as a nuclear medicine bleeding scan, or even CT or MR enterography can detect lesions if they are large enough. The typical treatment course for these lesions is surgical resection as there are no current data or consensus as to a safe and effective medical alternative for treatment.

\section{Conclusion}

This case report represents a rare finding of a small intestinal polyp consisting of heterotopic gastric mucosa that presented with severe iron deficiency anemia and lower gastrointestinal bleeding in a patient with a severe factor VII deficiency. Although rare, the presence of a bleeding lesion with gastric heterotopia should be included in the differential diagnosis of patients who present similarly. Fortunately, our patient did very well due to aggressive therapy for his bleeding disorder and suffered no unwanted side effects from his treatment. 


\section{Case Reports in Gastroenterology}

\begin{tabular}{l|l}
\hline DOI: 10.1159/000508441 & $\begin{array}{l}\text { (c) 2020 The Author(s). Published by S. Karger AG, Basel } \\
\text { www.karger.com/crg }\end{array}$ \\
\hline
\end{tabular}

Tibesar: Gastric Heterotopic Polyp in a Teenager with Bleeding Disorder

\section{Statement of Ethics}

The parents provided written informed consent for publication of their child's case.

\section{Conflict of Interest Statement}

The author has no conflicts of interest to declare.

\section{Funding Sources}

There were no funding sources for the preparation of this paper.

\section{References}

1 Terada T. Heterotopic gastric mucosa of the gastrointestinal tract: a histopathologic study of 158 cases. Pathol Res Pract. 2011 Mar;207(3):148-50.

2 Martínez A, Decanini-Terán 0, Soria-Céspedes D. Polypoid and hyperplastic heterotopic gastric mucosa in the jejunum as a cause of recurrent subocclusive episodes. Ann Gastroenterol. 2013;26(2):184.

3 Al-Jadaan S, Oda 0. A rare clinical presentation of heterotopic gastric mucosa of the jejunum: A case report and review of the literature. J Pediatr Surg Case Rep. 2014;2(7):337-40.

4 Leng S, Ghionzoli M, Caporalini C, Buccoliero AM. Long-term intestinal bleeding in a child: a rare case of heterotopic gastric mucosa in the jejunum. BMJ Case Rep. 2016 Nov 25;2016:bcr2016216949.

5 Cai J, Yu H. Giant polypoid gastric heterotopia in the small intestine in a boy: A case report and literature review. Medicine (Baltimore). 2017 Jan;96(1):e5854.

6 Genta RM, Kinsey RS, Singhal A, Suterwala S. Gastric foveolar metaplasia and gastric heterotopia in the duodenum: no evidence of an etiologic role for Helicobacter pylori. Hum Pathol. 2010 Nov;41(11):1593600.

7 Yu L, Yang Y, Cui L, Peng L, Sun G. Heterotopic gastric mucosa of the gastrointestinal tract: prevalence, histological features, and clinical characteristics. Scand J Gastroenterol. 2014 Feb;49(2):138-44.

8 Boybeyi O, Karnak I, Güçer S, Orhan D, Senocak ME. Common characteristics of jejunal heterotopic gastric tissue in children: a case report with review of the literature. J Pediatr Surg. 2008 Jul;43(7):e19-22.

9 Lambert MP, Heller DS, Bethel C. Extensive gastric heterotopia of the small intestine resulting in massive gastrointestinal bleeding, bowel perforation, and death: report of a case and review of the literature. Pediatr Dev Pathol. 2000 May-Jun;3(3):277-80.

10 Mungan Z. Is it Barrett's esophagus or gastric heterotopia? Case Rep Gastroenterol. 2014 Oct;8(3):282-5.

11 Lupu VV, Ignat A, Paduraru G, Mihaila D, Burlea M, Ciubara A. Heterotopic gastric mucosa in the distal part of esophagus in a teenager: case report. Medicine (Baltimore). 2015 Oct;94(42):e1722.

12 Alexander L, Abbas S, Alexander S. Symptomatic large ampullary gastric heterotopia. Gastrointest Endosc. 2018 Aug;88(2):402-3. 
Case Reports in Gastroenterology
Case Rep Gastroenterol 2020;14:467-471

DOI: $10.1159 / 000508441$

(c) 2020 The Author(s). Published by S. Karger AG, Basel www.karger.com/crg

Tibesar: Gastric Heterotopic Polyp in a Teenager with Bleeding Disorder

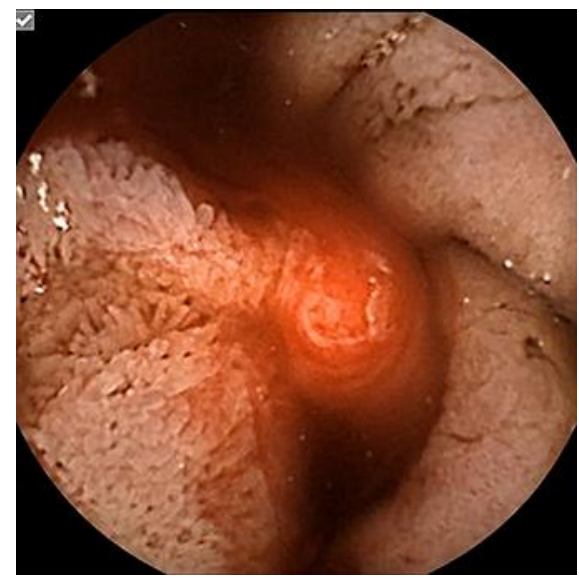

Fig. 1. Capsule endoscopy photograph of an active bleeding lesion in the third portion of the duodenum.
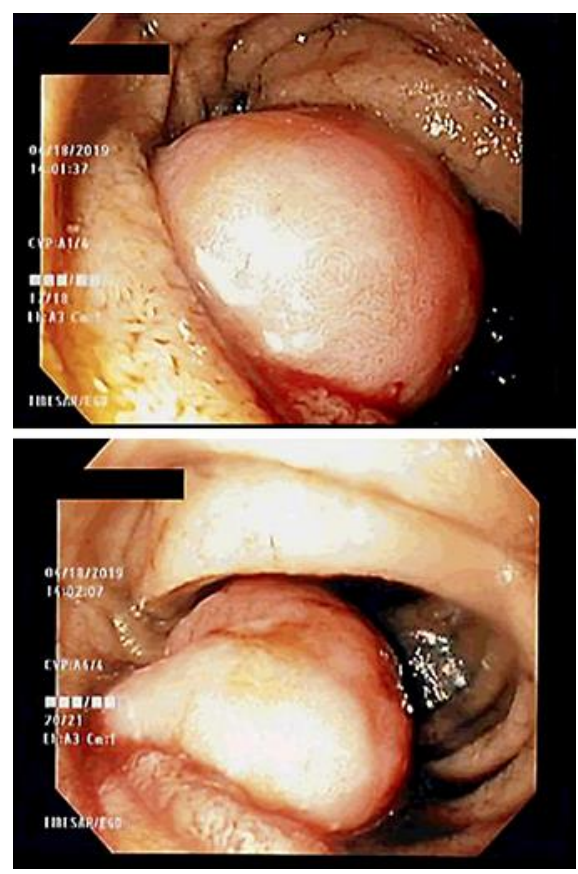

Fig. 2. Upper endoscopy photographs of a polypoid lesion located near the ligament of Treitz in the distal duodenum. 